\title{
Comparation of Leaf C/N/P Stoichiometry between Two Types of Branches of Ziziphus jujuba Mill. cv. Dongzao
}

\author{
Aiyun Song ${ }^{1}$, Linshui Dong ${ }^{1 *}$, Jingtao Liu ${ }^{1}$, Zhaofei Fan $^{2}$ \\ ${ }^{1}$ Shandong Key Laboratory of Eco-Environmental Science for Yellow River Delta, Binzhou University, \\ Binzhou, Shandong, China \\ ${ }^{2}$ School of Forestry and Wildlife Sciences, Auburn University, Auburn, Al, USA
}

Received: 30 December 2020

Accepted: 16 April 2021

\begin{abstract}
Carbon, nitrogen and phosphorus transport within the fruit tree are complex processes involving source-sink interactions. Understanding the difference of leaf stoichiometry between fruiting branches and vegetative branches of winter jujube (Ziziphus jujuba Mill. cv. Dongzao) can provide sight into the source-sink relationship. The study investigated the seasonal dynamics and the difference of the leaf stoichiometry between vegetative branches and fruiting branches of winter jujube. The study investigated the seasonal dynamics and the difference of the leaf stoichiometry between vegetative branches and fruiting branches of winter jujube. The results showed that the leaf $\mathrm{C}$ content was significantly higher $(p<0.05)$ in the fruiting branch than in the vegetative branch in most growth stages except for the Full flowering stage. The leaf $\mathrm{N}$ and $\mathrm{P}$ contents were both higher in vegetative branch than in fruiting branch in most growth stages, but only in a few growth stages, these differences reached a significant level. There was a significant correlation between the leaf stoichiometric indices examined such as $\mathrm{N}$ and $\mathrm{C} / \mathrm{N}, \mathrm{P}$ and $\mathrm{C} / \mathrm{P}, \mathrm{P}$ and $\mathrm{N} / \mathrm{P}, \mathrm{C} / \mathrm{P}$ and $\mathrm{N} / \mathrm{P}$. The result showed that $\mathrm{N}$ and $\mathrm{P}$ were the key factors to determine the element ratio. The winter jujube trees incurred $\mathrm{N}$ and $\mathrm{P}$ co-limitation $(14<\mathrm{N} / \mathrm{P}<16)$ in the Initial flowering stage and $\mathrm{P}$ limitation $(\mathrm{N} / \mathrm{P}>16)$ in other growth stages. Our study provides baseline information for describing the changes in nutritional elements with jujube growth, which will facilitate plantation management.
\end{abstract}

Keywords: fruiting branch, vegetative branch, stoichiometry, Ziziphus jujuba Mill. cv. Dongzao

*e-mail: donglinshui@163.com 


\section{Introduction}

Winter jujube (Ziziphus jujuba Mill. cv. Dongzao) is a fresh-eating and later-maturing cultivar of jujube of China with good taste and rich nutrition such as vitamin $\mathrm{C}$, amino acids, carbohydrates and minerals [1-3]. The winter jujube plantation is one of the leading industries in Zhanhua County of Shandong Province (an eastern Chinese province) and produces about $90 \%$ fresh winter jujube fruit of the commercial market $[4,5]$.

However, the production of winter jujube fruit has suffered a problem with great variations in its palatability, nutrition, sweetness and crispness which are closely related to soil fertility condition and tree fertilization regime (e.g., timing, amount and proportion of nutrients added). Ecological stoichiometry may be an effective method for predicting plant nutrient status and dynamics of natural plant or crop under varying soil fertility conditions $[6,7]$.

Carbon $(\mathrm{C})$, nitrogen $(\mathrm{N})$, and phosphorus $(\mathrm{P})$ are the key elements of the living organisms, and their concentrations and dynamics in plant tissues reflect nutrient uptake, utilization efficiency and adaptation to the environment during the different growth stages [8, 9]. For instance, the ratio of $\mathrm{N}$ and $\mathrm{P}$ of leaves (N/P) has been suggested to be useful for indicating the shift between $\mathrm{N}$ and $\mathrm{P}$ limitation [10, 11]. Previous studies proposed low leaf $\mathrm{N} / \mathrm{P}(<14)$ reflected $\mathrm{N}$ limitation, while the high $\mathrm{N} / \mathrm{P}(>16)$ likely reflected $\mathrm{P}$ limitation. In between $(14<\mathrm{N} / \mathrm{P}<16), \mathrm{N}$ and $\mathrm{P}$ were co-limiting [12, 13].

Leaf nutrient contents are dynamic and often depend on plant growth stage and soil condition [14, 15]. Whereas other previous studies have evaluated the stoichiometry characteristics of $\mathrm{C}, \mathrm{N}$, and $\mathrm{P}$ in the leaves, especially, the correlation between the photosynthetic $\mathrm{C}$ fixation and $\mathrm{N}, \mathrm{P}$ content of leaves during the growing seasons in some annual species or perennial plant cultivars [16-18]. However, previous studies have been performed on NP stoichiometric characteristics and dynamics to predict $\mathrm{N}$ or $\mathrm{P}$ limitations of horticultural crops for fruit yield or quality [19-21]. Increasing fruit load significantly decreased branch growth on horticultural tree species, ring-barking the branches further reduced their growth, and there is competition for carbohydrates and nutrients between fruits and shoots [22-24]. Considering all these points, the main objective of this study is to analyze the dynamic of leaf CNP stoichiometry in vegetative branches and fruiting branches of winter jujube in different growth stages.

\section{Materials and Methods}

\section{Plant Materials and Treatments}

The study site of winter jujube (Z. jujuba Mill. cv. Dongzao) plantation is located at the winter jujube research station of Binzhou University in Zhanhua County of Shandong Province, P. R. China, with a warm-temperate continental monsoon climate. The altitude is $7 \mathrm{~m}$. The average annual temperature is about to $12^{\circ} \mathrm{C}$ with a highest temperature of $40^{\circ} \mathrm{C}$ in July and the lowest temperature of $-15^{\circ} \mathrm{C}$ in January. The precipitation is about $557.7 \mathrm{~mm}$ annually [25]. The soil type is coastal saline tidal soil, and the soil properties are shown in Table 1.

Mature winter jujube trees grafted on Z. jujuba Mill. var. spinosa (Bunge) Hu ex H. F. Chow. rootstocks were used in this study. These jujube trees were planted at a density of $4 \mathrm{~m}$ by $2.5 \mathrm{~min} 2002$. The trees were maintained following regional commercial production practices. The winter jujube trees grew well and had mean diameter of $13.6 \mathrm{~cm}$.

\section{Sampling and Elements Measurements}

The leaf samples of winter jujube were collected from May to October in 2016 from ten randomly selected trees. According to the phenology of winter jujube, the leaf samples were collected at five growth stages, the specific sampling time included the Initial flowering stage (May $25^{\text {th }}$ ), Full flowering stage (June 20 ${ }^{\text {th }}$ ), Late flowering stage (July 23 $3^{\text {th }}$ ), Hardcore stage (August $28^{\text {th }}$ ) and Mature stage (October 10 $10^{\text {th }}$ [ [26]. The leaf samples on the fruiting branches and the vegetative branches were collected separately in each stage. The leaves were selected in four directions (East, West, South, and North) from a middle part of a crown of each sampling tree and fully mixed for preparation for chemical analysis. The dry leaves were ground through 60 mesh sieves. The total $\mathrm{C}$ and $\mathrm{N}$ contents of leaf samples were measured by element analyzer (Vario EL III, Elementar Inc., Germany). Total $\mathrm{P}$ of leaf was determined by the $\mathrm{HClO}_{4}-$ $\mathrm{H}_{2} \mathrm{SO}_{4}$ colorimetric method [27, 28].

\section{Statistical Analysis}

The indices including the contents of $\mathrm{C}, \mathrm{N}$, and $\mathrm{P}$, and the ratios of $\mathrm{C} / \mathrm{N}, \mathrm{C} / \mathrm{P}$, and $\mathrm{N} / \mathrm{P}$ were calculated based on leaf samples for the vegetative branches and the fruiting branches of each of the ten sample trees by each of the five growth stages. One-way ANOVA

Table 1. Average value of soil property indices of five random soil samples in study site.

\begin{tabular}{|c|c|c|c|c|c|c|}
\hline $\mathrm{pH}$ & $\begin{array}{c}\text { Bulk Density } \\
\left(\mathrm{g} \mathrm{cm}^{-3}\right)\end{array}$ & $\begin{array}{c}\text { Soil Organic Matter } \\
\left(\mathrm{g} \mathrm{kg}^{-1}\right)\end{array}$ & $\begin{array}{c}\text { Salt Content } \\
\left(\mathrm{g} \mathrm{kg}^{-1}\right)\end{array}$ & $\begin{array}{c}\text { Alkali-hydrolyzed } \\
\text { Nitrogen } \\
\left(\mathrm{mg} \mathrm{kg}^{-1}\right)\end{array}$ & $\begin{array}{c}\text { Available Phosphorus } \\
\left(\mathrm{mg} \mathrm{kg}^{-1}\right)\end{array}$ & $\begin{array}{c}\text { Available Potassium } \\
\left(\mathrm{mg} \mathrm{kg}^{-1}\right)\end{array}$ \\
\hline 7.78 & 1.21 & 17.78 & 2.20 & 27.81 & 54.22 & 120.92 \\
\hline
\end{tabular}


(Analysis of variance) was conducted to compare the means of all indices between the fruiting and vegetative branches. Multiple comparisons of the means of all indices by growth stage were conducted using the LSD (Least significant difference) test to evaluate the statistical significance. Pearson correlation was used to analyze the correlation among the indices. All tests were conducted using SPSS19.0 and OriginPro9.0 and chose a statistical significance level of 0.05 .

\section{Results}

\section{Dynamics of $\mathrm{C}, \mathrm{N}$, and P Content}

The average leaf $\mathrm{C}$ content of vegetative branch in the growing season ranged from 440.76 to $463.02 \mathrm{~g} \mathrm{~kg}^{-1}$, while the mean leaf $\mathrm{C}$ content of fruiting branches varied from 441.66 to $478.52 \mathrm{~g} \mathrm{~kg}^{-1}$ (Fig. 1a). Temporally, the leaf $\mathrm{C}$ content decreased from the Initial flowering stage to Full flowering stage, and then increased gradually from the Full flowering stage to Mature stage. The leaf $\mathrm{C}$ content of both kinds of branches were significantly higher in fruit stages than in the flowering stages. The leaf $\mathrm{C}$ content was significantly higher in fruiting branches than in vegetative branches in the same stage except in the Full flowering stage $(p<0.05)$.

The mean leaf $\mathrm{N}$ content of vegetative branches during the growth stages varied from 31.43 to $41.36 \mathrm{~g} \mathrm{~kg}^{-1}$, while the fruiting branches leaf $\mathrm{N}$ content varied from 28.86 to $42.15 \mathrm{~g} \mathrm{~kg}^{-1}$ (Fig. 1b). The leaf $\mathrm{N}$ content of vegetative branches decreased gradually from the Initial flowering stage to the Mature stage. However, the leaf $\mathrm{N}$ contents of fruiting branches were significantly higher in the Initial flowering stage than in the other stages. The leaf $\mathrm{N}$ contents of vegetative branches were higher than that of fruiting branches in the later stages except Initial flowering stage. There was significant difference between the leaf $\mathrm{N}$ contents of the two kinds of branches in the Full flowering stage and Late flowering stage $(p<0.05)$.

The mean leaf $\mathrm{P}$ contents of vegetative branches of winter jujube during the growth stages varied from 1.80 to $3.07 \mathrm{~g} \mathrm{~kg}^{-1}$, while the fruiting branches leaf $\mathrm{P}$ contents varied from 1.71 to $2.95 \mathrm{~g} \mathrm{~kg}^{-1}$ (Fig. 1c). The leaf $\mathrm{P}$ contents of both kinds of branches of winter jujube decreased gradually from the Initial flowering stage to the Mature stage. The leaf $\mathrm{P}$ contents of both kinds of branches in the Initial flowering stage were significantly higher than that in other growth stages. The leaf $\mathrm{P}$ contents of vegetative branches were all higher than that of fruiting branches in all the growth stages, but all the difference in each stage didn't reach significant level $(p<0.05)$.

\section{Dynamics of C, N, and P Ratios}

The mean leaf $\mathrm{C} / \mathrm{N}$ ratios of vegetative branches of winter jujube in each stage ranged from 10.74 to 14.74 ,
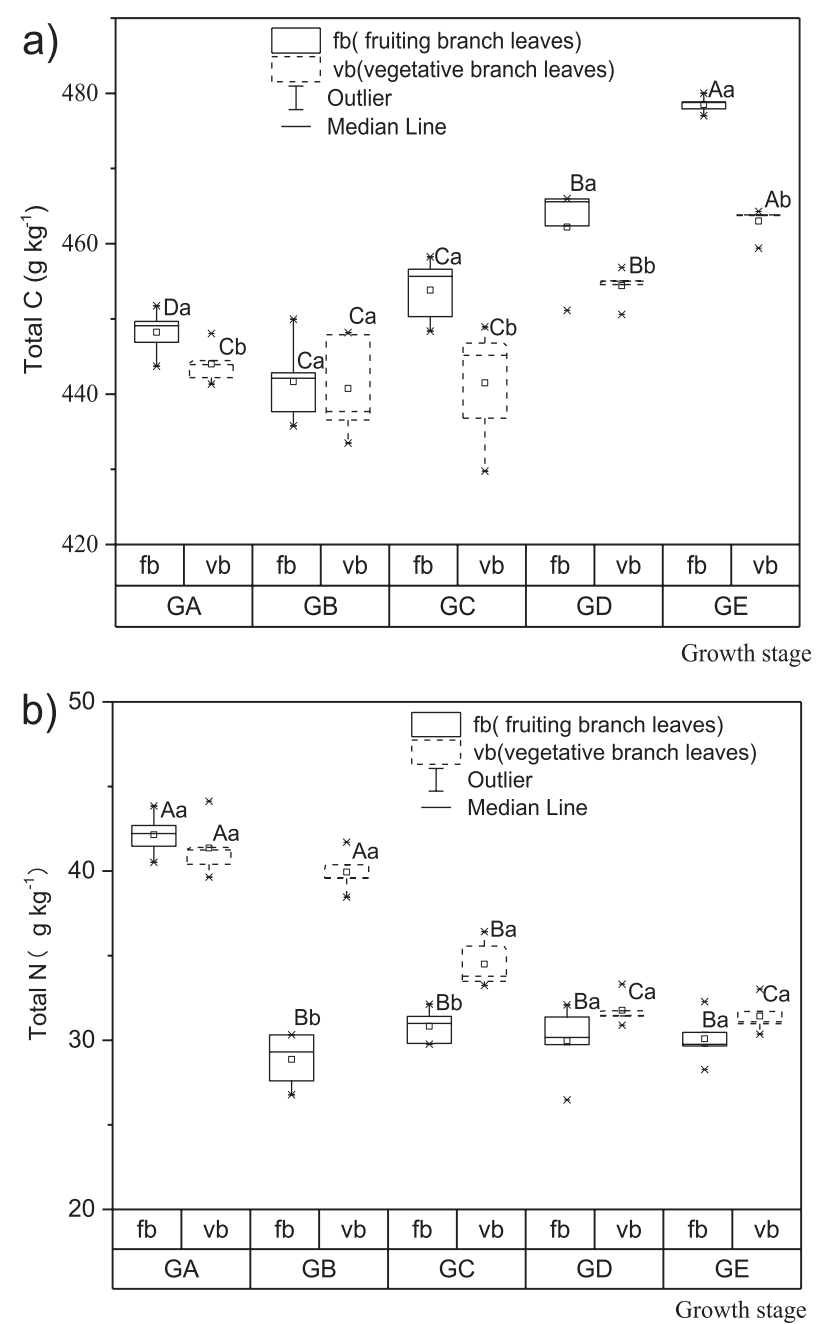

c)

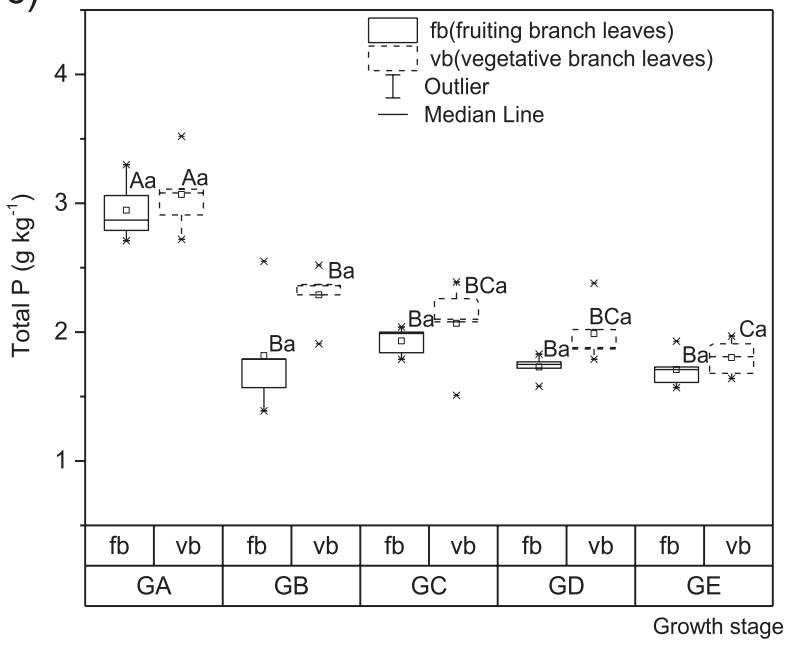

Fig. 1. Leaf $\mathrm{C} \mathrm{a}$ ), $\mathrm{N} \mathrm{b}$ ), and $\mathrm{P} \mathrm{c}$ ) content of fruiting branch and vegetative branch in different growth stages. Note: GA, GB, GC, GD, GE indicated Initial flowering stage, Full flowering stage, Late flowering stage, Hardcore stage, and Mature stage, respectively. fb indicated fruiting branch leaves, and vb indicated vegetative branch leaves. Different uppercase letters indicated significant difference among different growth stages for the same type of branch leaves $(p<0.05)$, and different lowercase letters indicated significant difference among two types of branch leaves in the same stage $(p<0.05)$. The same definitions are used throughout this paper. 

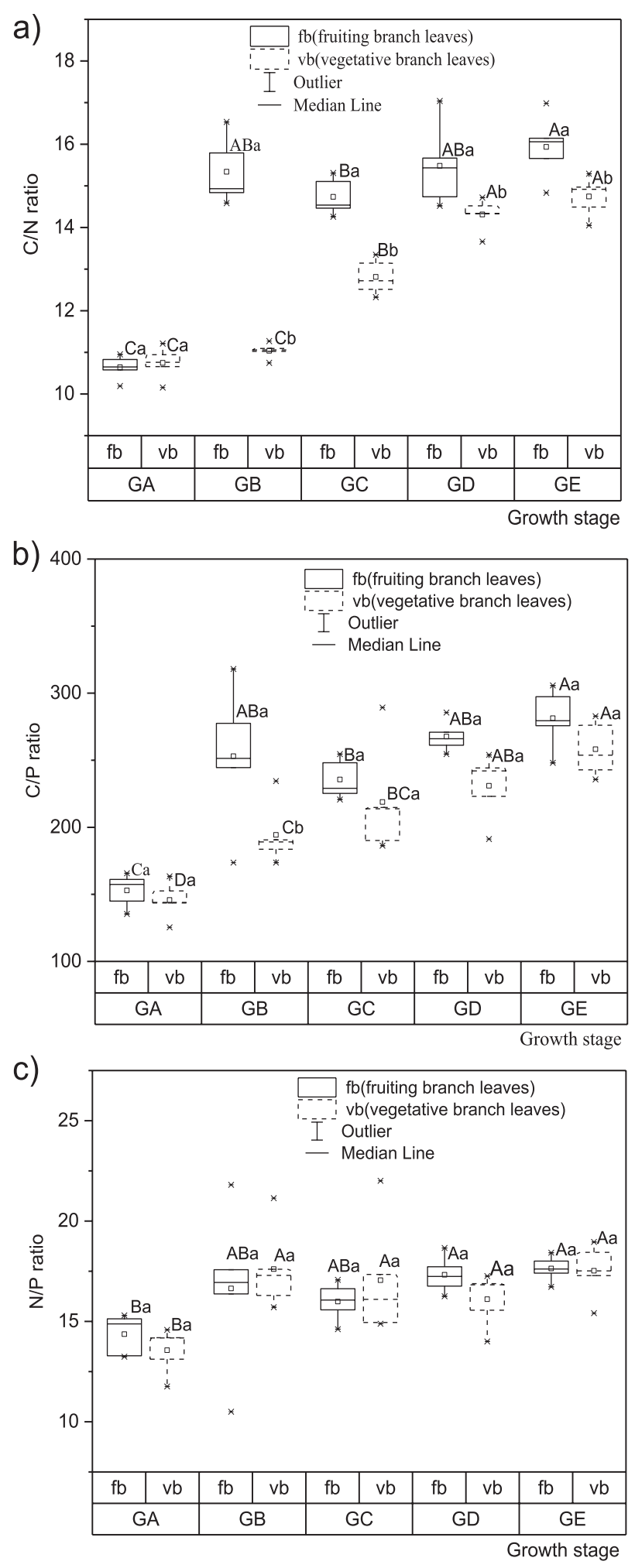

Fig. 2. The leaf $\mathrm{C} / \mathrm{N} \mathrm{a}$ ), $\mathrm{C} / \mathrm{P}$ b), N/P c) ratio of fruiting branch and vegetative branch in different growth stages. Note: GA, GB, GC, GD, GE indicated Initial flowering stage, Full flowering stage, Late flowering stage, Hardcore stage, and Mature stagegrowth stages respectively. $\mathrm{fb}$ indicated fruiting branch leaves, and $\mathrm{vb}$ indicated vegetative branch leaves. Different uppercase letters indicated significant difference among different growth stages for the same type of branch leaves $(p<0.05)$, and different lowercase letters indicated significant difference among two types of branch leaves in the same stage $(p<0.05)$. The same definitions are used throughout this paper. while the fruiting branches leaf $\mathrm{C} / \mathrm{N}$ varied from 10.64 to 15.93 (Fig. 2a). The leaf $\mathrm{C} / \mathrm{N}$ of vegetative branches increased gradually during the five different growth stages, and the leaf $\mathrm{C} / \mathrm{N}$ ratios in the Initial flowering stage and Full flowering stage were significantly lower than other three growth stages $(p<0.05)$. The leaf $\mathrm{C} / \mathrm{N}$ ratios of fruiting branches in the Initial flowering stage were significantly lower than that of the latter four growth stages $(p<0.05)$. The leaf $\mathrm{C} / \mathrm{N}$ ratios of vegetative branches in the growth stages except the Initial flowering stage were all significantly lower than that of fruiting branches.

The mean leaf $\mathrm{C} / \mathrm{P}$ ratios of vegetative branches during the growth stages ranged from 145.79 to 258.24 , while the fruiting branches leaf $\mathrm{C} / \mathrm{P}$ ratios varied from 152.94 to 281.29 (Fig. 2b). The leaf $\mathrm{C} / \mathrm{P}$ ratios of vegetative branches increased gradually during the five growth stages. The leaf $\mathrm{C} / \mathrm{P}$ ratios of fruiting branches in the Initial flowering stage were significantly lower than that of the other four growth stages $(p<0.05)$. The leaf $\mathrm{C} / \mathrm{P}$ ratios of vegetative branches in each stage were lower than that of fruiting branches, but the difference was significant only in the Full flowering stage $(p<0.05)$.

The mean leaf $\mathrm{N} / \mathrm{P}$ ratios of vegetative branches in the whole growing season ranged from 13.56 to 17.60 , while the fruiting branches leaf N/P ratios varied from 14.36 to 17.36 (Fig. 2c). While, most of the mean leaf $\mathrm{N} / \mathrm{P}$ ratios from the Full flowering stage to the Mature stage were in the range of 16 to 17.60 . The leaf N/P of vegetative branches in the Initial flowering stage were significantly lower than that of other stages. The leaf $\mathrm{N} / \mathrm{P}$ ratios of fruiting branches in the Initial flowering stage were significantly lower than that in the Hardcore stage or Mature stage. There was no significant difference observed between the leaf $\mathrm{N} / \mathrm{P}$ ratios of the two kinds of branches in each stage $(p<0.05)$.

\section{The Correlation of C, N, P and Their Ratios}

The relationship between all the leaf $\mathrm{C} / \mathrm{N} / \mathrm{P}$ and their ratios of both kinds of branches in each growth stage was analyzed by pearson's correlation coefficient (Table 2). The leaf $\mathrm{C}$ and the leaf $\mathrm{N}$ had significant positive correlation in the Initial flowering stage, Full flowering stage and Hardcore stage $(p<0.05)$. The leaf $\mathrm{C}$ and the leaf $\mathrm{P}$ had significant positive correlation only in the Initial flowering stage. The leaf $\mathrm{N}$ and the leaf $\mathrm{P}$ had significant positive correlation in the Initial flowering stage and Hardcore stage.

The leaf $\mathrm{C}$ had significant positive correlation with the leaf $\mathrm{C} / \mathrm{P}$ in the Full flowering stage and later flowering stage $(p<0.05)$. While, the leaf $\mathrm{C}$ and leaf N/P had highly significant positive correlation in the Full flowering stage and Later flowering stage $(p<0.01)$. The leaf $\mathrm{N}$ and the leaf $\mathrm{C} / \mathrm{N}$ had always highly significant negative correlation in each stage. The leaf $\mathrm{N}$ and the leaf $\mathrm{C} / \mathrm{P}$ had significant negative correlation only in the Initial flowering stage. The leaf $\mathrm{N}$ and the leaf $\mathrm{N} / \mathrm{P}$ in 
Table 2. Correlation analysis of leaf CNP contents and their ratios of winter jujube.

\begin{tabular}{|c|c|c|c|c|c|c|}
\hline Growth stage & & Leaf C & Leaf N & Leaf P & Leaf C/N & Leaf $\mathrm{C} / \mathrm{P}$ \\
\hline \multirow{5}{*}{ Initial flowering stage } & Leaf N & $0.342^{*}$ & & & & \\
\hline & Leaf $\mathrm{P}$ & $0.352^{*}$ & $0.475^{*}$ & & & \\
\hline & Leaf $\mathrm{C} / \mathrm{N}$ & 0.206 & $-0.847^{* *}$ & -0.291 & & \\
\hline & Leaf C/P & -0.140 & $-0.430^{*}$ & $-0.968^{* *}$ & $0.363^{*}$ & \\
\hline & Leaf N/P & -0.252 & -0.058 & $-0.897^{* *}$ & -0.089 & $0.895^{* *}$ \\
\hline \multirow{5}{*}{ Full flowering stage } & Leaf $N$ & $0.305^{*}$ & & & & \\
\hline & Leaf P & -0.297 & 0.077 & & & \\
\hline & Leaf $\mathrm{C} / \mathrm{N}$ & -0.143 & $-0.977^{* *}$ & -0.104 & & \\
\hline & Leaf C/P & $0.387^{*}$ & -0.151 & $-0.953^{* *}$ & 0.206 & \\
\hline & Leaf N/P & $0.483^{* *}$ & $0.460^{* *}$ & $-0.795^{* *}$ & $-0.401^{a}$ & $0.796^{* *}$ \\
\hline \multirow{5}{*}{ Late flowering stage } & Leaf N & 0.200 & & & & \\
\hline & Leaf $\mathrm{P}$ & -0.228 & 0.266 & & & \\
\hline & Leaf C/N & 0.177 & $-0.926^{* *}$ & $-0.339^{*}$ & & \\
\hline & Leaf C/P & $0.347^{*}$ & -0.164 & $-0.956^{* *}$ & 0.282 & \\
\hline & Leaf N/P & $0.401^{* *}$ & 0.210 & $-0.883^{* *}$ & -0.071 & $0.946^{* *}$ \\
\hline \multirow{5}{*}{ Hardcore stage } & Leaf N & $0.392^{*}$ & & & & \\
\hline & Leaf $P$ & -0.002 & $0.316^{*}$ & & & \\
\hline & Leaf $\mathrm{C} / \mathrm{N}$ & -0.024 & $-0.924^{* *}$ & $-0.344^{*}$ & & \\
\hline & Leaf C/P & 0.207 & -0.263 & $-0.950^{* *}$ & $0.366^{*}$ & \\
\hline & Leaf N/P & 0.234 & 0.159 & $-0.860^{* *}$ & -0.084 & $0.896^{* *}$ \\
\hline \multirow{5}{*}{ Mature stage } & Leaf $N$ & 0.050 & & & & \\
\hline & Leaf $P$ & 0.011 & 0.220 & & & \\
\hline & Leaf C/N & 0.213 & $-0.962^{* *}$ & -0.214 & & \\
\hline & Leaf C/P & 0.155 & -0.204 & $-0.979^{* *}$ & 0.242 & \\
\hline & Leaf N/P & 0.041 & $0.344^{*}$ & $-0.832^{* *}$ & $-0.325^{*}$ & $0.837^{* *}$ \\
\hline
\end{tabular}

Note: ${ }^{*},{ }^{* *}$ denote significance at the $0.05,0.01$ test level, respectively. In this text, the "significant" and "highly significant"correlations refer to significance at the 0.05 and 0.01 test level, respectively.

the Full flowering stage and Mature stage had highly significant positive and significant positive correlation, respectively. The leaf $\mathrm{P}$ and the leaf $\mathrm{C} / \mathrm{N}$ had significant negative correlation in the Late flowering stage and Hardcore stage. The leaf $\mathrm{P}$ and the leaf $\mathrm{C} / \mathrm{P}$ had highly significant negative correlation in all the five stages, and the correlation coefficient varied from -0.950 to -0.979 . The leaf $\mathrm{P}$ and the leaf N/P also had highly significant negative correlation in all the five stages.

\section{Discussion}

Generally, the leaves of different tree species have different nutrient contents and stoichiometric characteristics as a result of their different nutrient requirements and use efficiencies [29]. Leaf C, N and
P stoichiometry have certain indicative effects on the growth rate, adaptation strategy, nutrient limitation, and community function of plants [30].

The average leaf $\mathrm{C}$ content (440.76-478.52 $\mathrm{g} \mathrm{kg}^{-1}$ ) of winter jujube in each growth stage of the growing season was lower than the average leaf $\mathrm{C}$ content (480.10 $\mathrm{g} \mathrm{kg}^{-1}$ ) from 102 dominant species in forest ecosystems along the North-South Transect of East China [31] and slightly higher than the mean value $\left(438.00 \mathrm{~g} \mathrm{~kg}^{-1}\right)$ from 126 plant species in loess plateau of China [32], and similar to apple with the mean leaf $\mathrm{C}$ ranging from 454.2 to $471.9 \mathrm{~g} \mathrm{~kg}^{-1}$ [33].

The mean leaf $\mathrm{N}$ content (28.86-42.15g kg-1) of winter jujube during the growing season was higher than the mean leaf $\mathrm{N}$ content $\left(21.12 \mathrm{~g} \mathrm{~kg}^{-1}\right)$ of 156 deciduous woody species in east China [34], and also higher than the leaf $\mathrm{N}$ content (8.40-30.50 $\left.\mathrm{g} \mathrm{kg}^{-1}\right)$ 
of 102 dominant species in forest ecosystem along the North-South Transect of East China [31]. The leaf N content (21.88- $28.80 \mathrm{~g} \mathrm{~kg}^{-1}$ ) of apple in different area of China was also slightly lower than that of winter jujube [33]. The leaf $\mathrm{N}$ content of winter jujube in this study was similar with the leaf $\mathrm{N}$ content (24.95-31.22 $\left.\mathrm{g} \mathrm{kg}^{-1}\right)$ of Zizyphus jujuba CV. Tongxinyuanzao [35], and also similar with the leaf $\mathrm{N}$ content (27.13-49.54 $\mathrm{g} \mathrm{kg}^{-1}$ ) of Zizyphus jujuba CV. Junzao during the growth stages [36].

The leaf P content (1.71-3.07 $\left.\mathrm{g} \mathrm{kg}^{-1}\right)$ of winter jujube was higher than the mean leaf $\mathrm{P}$ content $\left(1.55 \mathrm{~g} \mathrm{~kg}^{-1}\right)$ of 182 deciduous woody plant species in east China [28], and also higher than the mean leaf $P\left(1.60 \mathrm{~g} \mathrm{~kg}^{-1}\right)$ of 126 plant species in loess plateau of China [26]. The leaf $\mathrm{P}$ content (1.35-1.67 $\mathrm{g} \mathrm{kg}^{-1}$ ) of apple in different area of China was also slightly lower than that of winter jujube [33]. The leaf $\mathrm{P}$ content of winter jujube from the Full flowering stage to the Mature stage was similar to the mean leaf P content (2.21-2.76 $\mathrm{g} \mathrm{kg}^{-1}$ ) of Zizyphus jujuba 'Tongxinyuanzao' [35].

By comparison, the mean leaf $\mathrm{N}$ and $\mathrm{P}$ content of winter jujube were higher than that of many natural plant species, and also the value was higher than that of apple in China. Leaves of winter jujube had higher concentration of leaf $\mathrm{N}$ and $\mathrm{P}$ than natural tree species, indicating an greater dependence of the tree on soil nutrient in the growing season. Whether the jujube plants (Ziziphus Mill.) in the cultivation environment have relatively high nitrogen and phosphorus content is worthy of further study in the future.

The leaf $\mathrm{C} / \mathrm{N}$ ratio (10.64-15.93) of winter jujube during the five growth stages was much lower than the mean leaf $\mathrm{C} / \mathrm{N}$ ratio $(29.10$, in the range from 14.10 to 64.10) of 102 dominant species in forest ecosystems of east China [31], and also lower than the mean leaf $\mathrm{C} / \mathrm{N}$ ratio (17.30) of 358 plant species in Beijing of China and the leaf $\mathrm{C} / \mathrm{N}$ ratios $(16.44-21.44)$ of apple in different area of China [33, 37].

The leaf C/P ratio (145.79-281.29) of winter jujube was lower than the average leaf $\mathrm{C} / \mathrm{P}$ ratio (313.90) of 102 dominant species in forest ecosystems of east China [31] and the mean leaf $\mathrm{C} / \mathrm{P}$ ratio (312.00) of 126 plant species in loess plateau of China [32], and also lower than the mean leaf $\mathrm{C} / \mathrm{P}$ ratio (281.24-354.28) of apple trees in different area of China [33].

The leaf N/P ratio (13.56-17.60) of winter jujube during all the growth season was higher than the mean leaf N/P ratio (12.76) of 154 deciduous woody plant species in east China [34], and slightly higher than the mean leaf $\mathrm{N} / \mathrm{P}$ ratio (13.90) of 358 plant species in Beijing of China [37].

Previous study showed that the leaf N/P ratio was lower than 14 often indicated $\mathrm{N}$ limitation, on the other hand N/P ratio that was higher than 16 showed $\mathrm{P}$ limitation, in between $(14<\mathrm{N} / \mathrm{P}<16), \mathrm{N}$ and $\mathrm{P}$ were colimiting $[14,38]$. Compare all these numerical range, the winter jujube plantation had $\mathrm{N}$ and $\mathrm{P}$ co-limitation in the Initial flowering stage, while there was P limitation in other growth stages [39, 40].

\section{Conclusion}

The leaf $\mathrm{C}$ content of fruiting branch was all higher than that of the vegetative branch in the each growing stage, and significant differences were observed between different growth stages except for Full flowering stage $(p<0.05)$. Whereas, the mean leaf $\mathrm{N}$ and leaf $\mathrm{P}$ contents of vegetative branches were both higher than that of fruiting branches in most growth stages.

Comparing the results of previous studies, the winter jujube plantation had $\mathrm{N}$ and $\mathrm{P}$ co-limitation in the Initial flowering stage, while there was P limitation in other growth stages.

The correlation analysis showed that some indices pairs including leaf $\mathrm{N}$ and leaf $\mathrm{C} / \mathrm{N}$, leaf $\mathrm{P}$ and leaf $\mathrm{C} / \mathrm{P}$, leaf $\mathrm{P}$ and leaf N/P, leaf $\mathrm{C} / \mathrm{P}$ and leaf $\mathrm{N} / \mathrm{P}$ had closely relationship. The correlation between leaf $\mathrm{N}$ and leaf $\mathrm{C} / \mathrm{N}$ was much more strongly than that between leaf $\mathrm{C}$ and leaf $\mathrm{C} / \mathrm{N}$, and the correlation between leaf $\mathrm{P}$ and $\mathrm{C} / \mathrm{P}$ was also much more strongly than that between leaf $\mathrm{C}$ and $\mathrm{C} / \mathrm{P}$. In the future research, the relationship among fertilization, leaf stoichiometric characteristics and fruit quality should be focused on.

\section{Acknowledgements}

This work was supported by the National Key Research and Development Program of China (grant No. 2017YFC0505904), the Science and Technology Development Project of Shandong Province (grant No. 2014GNC110018), the Natural Science Foundation of Shandong Province (grant No. ZR2020QC168).

\section{Conflicts of Interest}

The authors declare no conflict of interest.

\section{References}

1. TIAN X.L., LI C., WANG Z.A., XIA L.Y., ROBBAT A.J. Application of feature selection algorithms to select elements that distinguish regional differences in Chinese grown winter jujube fruit (Zizyphus jujuba Mill. cv. Huanghua Dongzao). Food Analytical Methods, 13, 1, 2020.

2. JING D.W., DU Z.Y., MA H.L., MA B.Y., LIU F.C., SONG Y.G., XU Y.F., LI L. Selenium enrichment, fruit quality and yield of winter jujube as affected by addition of sodium selenite. Scientia Horticulturae, 225, 1, 2017.

3. ZHANG M., WANG Y., WEN C.Y., WU H.Y. First Report of Fusarium proliferatum Causing Fruit Rot of Winter Jujube (Ziziphus jujuba) in Storage in China. Plant Disease 96, 913, 2012. 
4. KOU X.H., HE Y.L., LI Y.F., CHEN X.Y., FENG Y.C., XUE Z.H. Effect of abscisic acid (ABA) and chitosan/ nano-silica/sodium alginate composite film on the color development and quality of postharvest Chinese winter jujube (Ziziphus jujuba Mill. cv. Dongzao). Food Chemistry 270, 385, 2019.

5. ZHANG L.Z., LI S.F., DONG Y., ZHI H., ZONG W. Tea polyphenols incorporated into alginate-based edible coating for quality maintenance of Chinese winter jujube under ambient temperature. LWT-Food Science \& Technology 70, 155, 2016.

6. ANDERSON T.M., GRIFFITH D.M., GRACE J.B., LIND E.M., ADLER P.B., BIEDERMAN L.A., BLUMENTHAL D.M., DALEO P., FIRN J., HAGENAH N. Herbivory and eutrophication mediate grassland plant nutrient responses across a global climatic gradient. Ecology 99, 822, 2018.

7. CARRILLO Y., BELL C., KOYAMA A., CANARINI A., BOOT C., WALLENSTEIN M., PENDALL E. Plant traits, stoichiometry and microbes as drivers of decomposition in the rhizosphere in a temperate grassland. Journal of Ecology 105, 1750, 2017.

8. KOPITTKE P.M., DALAL R.C., FINN D., MENZIES N.W. Global changes in soil stocks of carbon, nitrogen, phosphorus, and sulphur as influenced by long-term agricultural production. Global Change Biology 23, 2509, 2017.

9. WIGLEY B.J., SLINGSBY J.A., DIAZ S., BOND W.J., FRITZ H., COETSEE C. Leaf traits of African woody savanna species across climate and soil fertility gradients: evidence for conservative versus acquisitive resource-use strategies. Journal of Ecology 104, 1357, 2018.

10. BLANES M.C., EMMETT B.A., VIÑEGLA B., CARREIRA J.A. Alleviation of P limitation makes tree roots competitive for $\mathrm{N}$ against microbes in a $\mathrm{N}$-saturated conifer forest: A test through $\mathrm{P}$ fertilization and ${ }^{15} \mathrm{~N}$ labelling. Soil Biology \& Biochemistry 48, 51, 2012.

11. SCHREEG L.A., SANTIAGO L.S., WRIGHT S.J., TURNER B.L. Stem, root, and older leaf N:P ratios are more responsive indicators of soil nutrient availability than new foliage. Ecology 95, 2062, 2014.

12. GÜSEWELL, S. N:P ratios in terrestrial plants: variation and functional significance. New Phytologist 164, 243, 2004

13. KOERSELMAN W., MEULEMAN A. The vegetation N:P ratio: a new tool to detect the nature of nutrient limitation. Journal of Applied Ecology 33, 1441, 1996.

14. ACHAT D., POUSSE N., NICOLAS M., AUGUSTO L. Nutrient remobilization in tree foliage as affected by soil nutrients and leaf life span. Ecological Monographs 88, 408, 2018.

15. MAYOR J.R., WRIGHT S.J., TURNER B.L., AUSTIN A. Species-specific responses of foliar nutrients to long-term nitrogen and phosphorus additions in a lowland tropical forest. Journal of Ecology 102, 36, 2014.

16. SARDANS J., RIVAS-UBACH A., PEÑUELAS J. Factors affecting nutrient concentration and stoichiometry of forest trees in Catalonia (NE Spain). Forest Ecology and Management 262, 2024, 2011.

17. ZHANG R., PAN H.W., HE B.T., CHEN H.W., ZHOU Z.C. Nitrogen and phosphorus stoichiometry of Schima superba under nitrogen deposition. Scientific Reports 8, 13669, 2018.

18. LI F., HU J.Y., XIE Y.H., YANG G.S., HU C., CHEN X.S., DENG Z.M. Foliar stoichiometry of carbon, nitrogen, and phosphorus in wetland sedge Carex brevicuspis along a small-scale elevation gradient. Ecological Indicators 92, 322, 2017.

19. ARBA M., FALISSE A., CHOUKR-ALLAH R., SINDIC M. Effects of nitrogen and phosphorus fertilization on fruit yield and quality of cactus pear Opuntia ficus-indica (L.) Mill. Fruits 72, 212, 2017

20. THAMRIN M., SUSANTO S., SUSILA A.D., SUTA D.A. Correlation between nitrogen, phosphorus and potassium leaf nutrient with fruit production of Pummelo citrus (Citrus maxima). Asian Journal of Applied Sciences 7, 129, 2014.

21. ANDRÉS O., SCOTT J., QIN X.Q., CARLOS H.C. Fruit phosphorous and nitrogen deficiencies affect 'Grand Pearl' nectarine flesh browning. Hortscience 47, 391, 2012.

22. STANDER O.P.J., BARRY G.H., CRONJÉ P.J.R. Fruit load limits root growth, summer vegetative shoot development, and flowering in alternate-bearing 'Nadorcott' mandarin trees. American Society for Horticultural science 143, 213, 2018.

23. BENOÎT P., SYLVIE B., JÉRÔME N., SÉBASTIEN M., ANNE C.V., JEAN-JACQUES K., EVELYNE C. Growth and carbon balance are differently regulated by tree and shoot fruiting contexts: an integrative study on apple genotypes with contrasted bearing patterns. Tree Physiology 38, 1395, 2018.

24. BELÉN M.A., DOMINGO J.I., CARMINA R., CARLOS M., MANUEL A., EDUARDO P.M. Carbon utilization by fruit limits shoot growth in alternate-bearing citrus trees. Journal of Plant Physiology 176, 108, 2015.

25. CAI Y.W., REN J.C. Precipitation change and agricultural drought and flood degrees during crop growth season in binzhou city. Meteorological and Environmental Research, 5, 46, 2014

26. KRISHNA H., KUMAR L., HALDHAR S.M., HALDHAR S.M., SINGH D., SAROJ P.L. Phenological growth stages of Indian jujube (Ziziphus mauritiana Lamk.) according to the BBCH scale. Annals of Applied Biology 174, 106, 2019.

27. JOHN M. Colorimetric determination of phosphorus in soil and plant materials with ascorbic acid. Soil Science 109, 214, 1970.

28. SCOTT E., PRATER C., NORMAN E., BAKER B., EVANS-WHITE M., SCOTT J. Leaf-litter stoichiometry is affected by streamwater phosphorus concentrations and litter type. Freshwater Science 32, 753, 2013.

29. PAN F.J., ZHANG W., LIU S.J., LI D.J., WANG K.L. Leaf $\mathrm{N}: \mathrm{P}$ stoichiometry across plant functional groups in the karst region of southwestern China. Trees 29, 883, 2015.

30. TONG, R., ZHOU B.Z., JIANG L.N., GE X.G., CAO Y.H. YANG Z.Y. Leaf nitrogen and phosphorus stoichiometry of Chinese fir plantations across China: A Meta-Analysis. Forests 10, 945, 2019.

31. REN S.J., YU G.R., JIANG C.M., FANG H.J., SUN X.M. Stoichiometric characteristics of leaf carbon, nitrogen, and phosphorus of 102 dominant species in forest ecosystems along the North-South Transect of East China. Chinese Journal of Applied Ecology 23, 581, 2012.

32. ZHENG S.X., SHANGGUAN Z.P. Spatial patterns of leaf nutrient traits of the plants in the Loess Plateau of China. Trees 21, 357, 2007.

33. ZHANG D., WANG C., LI X., YANG X., ZHAO L., LIU L., ZHU C., LI R. Linking plant ecological stoichiometry with soil nutrient and bacterial communities in apple orchards. Applied Soil Ecology 126, 1, 2018. 
34. REN S.J., YU G.R., TAO B., WANG S.Q. Leaf nitrogen and phosphorus stoichiometry across 654 terrestrial plant species in NSTEC. Environment Science 28, 2665, 2007.

35. YAN P.K., YU R., WANG D.Q., HOU T., GUO P.F., ZHOU X.R., SUN Q., WANG R. Annual dynamic change of N, P and $\mathrm{K}$ contents as well as fertilizer requirement of jujube trees (Zizyphus jujuba 'Tongxinyuanzao') in Ningxia. Journal of Fruit Science 37, 77, 2020.

36. ZHI J.H., WU C.Y., WANG H.L., CHEN Q.L., ZHENG Q.Q., CAI J.J. Influence of different application amounts of potassium fertilizer on the dynamics of nitrogen nutrition for soil and plants in the jujube orchards. Biotechnology 14, 165, 2015.

37. HAN W.X., WU Y., TANG L.Y., CHEN Y.H., LI L.P., HE J.S., FANG J.Y. Leaf carbon, nitrogen and phosphorus stoichiometry across plant species in Beijing and its periphery. Acta Scientiarum Naturalium Universitatis Pekinensis 45, 855, 2009.

38. NIKLAS K.J., COBB E.D. Biomass partitioning and leaf N, P-stoichiometry: comparisons between tree and herbaceous current-year shoots. Plant Cell and Environment 29, 2030, 2006.

39. ALVAREZ-CLARE S., MACK M.C. Do foliar, litter, and root nitrogen and phosphorus concentrations reflect nutrient limitation in a lowland tropical wet forest?. PLOS ONE 10, e0123796, 2015.

40. TONG R., ZHOU B.Z., JIANG L.N., GE X.G., CAO Y.H. The growth of Chinese fir is limited by nitrogen: Evidences from $\mathrm{N}: \mathrm{P}$ ratio, $\mathrm{N}$ or $\mathrm{P}$ variability and $\mathrm{NuRE}$ based on a regional investigation. Forest Ecology and Management 460, 117905, 2020 